\title{
ECOLOGY OF MARGARITIFERA MARGARITIFERA (BIVALVIA, MARGARITIFERIDAE) IN THE RIVER KAMENNAYA, WHITE SEA BASIN, RUSSIA
}

\author{
Alexey A. Zotin ${ }^{1}$, Svetlana A. Murzina ${ }^{2} \mathbb{D}^{D}$, Denis A. Efremov ${ }^{2}$, Panu Oulasvirta $^{3}$, Evgeny P. Ieshko ${ }^{2}$ \\ ${ }^{1}$ Koltsov Institute of Developmental Biology of RAS, Russia \\ e-mail:aazotin@mail.ru \\ ${ }^{2}$ Institute of Biology of the Karelian Research Centre of RAS, Russia \\ e-mail:murzina.svetlana@gmail.com,denisefremov@list.ru,ieshkoep@gmail.com \\ ${ }^{3}$ Alleco Ltd., Finland \\ e-mail:panu.oulasvirta@alleco.fi
}

Received: 16.05.2020. Revised: 11.10.2020. Accepted: 25.10.2020.

\begin{abstract}
The conditions for cohabitation of juvenile Salmo salar and Margaritifera margaritifera in the River Kamennaya (River Kem catchment, White Sea drainage basin, Russia) were studied. The M. margaritifera population in the River Kamennaya contains about 1000 specimens. The only intermediate host capable of sustaining the existence of this rare North European mussel is the juvenile $S$. salar. In this study, we investigated a set of parameters and processes to get a more comprehensive insight into the ecology of the M. margaritifera. One of such parameters is the individual linear growth, which was investigated in freshwater mussels from the River Kamennaya. Growth deceleration coefficients varied widely and differed significantly among specimens. The population-averaged coefficient of growth deceleration was 0.076 . The growth of mussels in the River Kamennaya involves three regular biorhythms with the following periods: $11.5,6.4$ and 4.0 years. The biorhythm periods were roughly constant both through an individual's ontogeny and among different individuals. A comparison of our results with data on other M. margaritifera populations in the Republic of Karelia and the Murmansk Region reveals a reliable $(p<0.01)$ negative correlation between growth deceleration coefficients and mean annual temperature in the $M$. margaritifera habitat. The abundance, spatial distribution and age structure of juvenile $S$. salar and $M$. margaritifera are presented. The rates of glochidial infection in $S$. salar juveniles at different ages were estimated. The developmental stages and the status of glochidia encysted on juvenile $S$. salar gills were observed and described using histological methods. The results of this study will be used to suggest activities and measures aimed to preserve populations of M. margaritifera and $S$. salar in the River Kamennaya, primarily to promote juvenile $S$. salar numbers and $M$. margaritifera settlement in rapids with a high density of young individuals.
\end{abstract}

Key words: Atlantic salmon, endangered species conservation, freshwater pearl mussel, glochidia, growth, infection, Salmo salar

\section{Introduction}

Among rivers of the Green Belt of Fennoscandia, Margaritifera margaritifera Linnaeus, 1758 colonies in the River Kem are best known as places of intense pearl fishing in the XVIII century (Makhrov et al., 2014). The River Pista flows into Lake Verkhnee Kuito east of Voinitsa, It was considered as the best «pearl river» in the Kalevala rural area in the Republic of Karelia (hereafter - Karelia) (Inha, 1999).

Margaritifera margaritifera is a threatened species in the European fauna. The conservation status of this species is fixed in Appendix III of the Bern Convention (Council of Europe, 1979), Kotiranta et al. (1998), Ziuganov \& Zotin (2001), Artemyev (2007). In the IUCN Red List of Threatened Animals (IUCN, 2020), it is listed as Endangered taxon. Nowadays, $95-100 \%$ of $M$. margaritifera populations are considered to be on the verge of extinction in central and southern Europe (Bauer, 1986, 1988). Sustainable populations with active breeding have been preserved in Canada (Kennedy et al., 2020), northwestern Russia (Ziuganov et al., 1994), Sweden (Dunca \& Mutvei, 2009; Olofsson, 2017), Finland (Oulasvirta et al., 2017), Norway (Dolmen \& Kleiven, 2008), Germany (Denic \& Geist, 2017), Ireland (Moorkens, 2010) and Great Britain (Young et al., 2001; Lavictoire et al., 2018). Small colonies have survived in Spain (Outeiro et al., 2007), Portugal (Sousa et al., 2013), Belgium (Motte et al., 2013), France (Cochet, 2004), Luxembourg (Arendt et al., 2010), Poland (Dyduch-Falniowska \& Zając, 2005), Latvia (Rudzīte et al., 2017), Estonia (Geist, 2010), Czech Republic (Simon et al., 2015), and Austria (Gumpinger et al., 2016). 
The growth of poikilotherm animals largely depends on the external environment, most essentially on temperature (Alimov, 1981). Among other poikilotherm organisms, bivalves are regarded as the most significant group for the study of the relationship between growth parameters and environmental conditions. Bivalves in general and Margaritiferidae mussels in particular have record-bearing structures, named as annual growth rings, which appear due to growth inhibition in winter. Changes in annual ring length enable studies of linear growth patterns both in different mussel populations and, retrospectively, within a population (Bauer, 1992). Thus, growth parameters act as a proxy of past environmental changes in the ecosystem.

Numerous studies of $M$. margaritifera helped to identify some patterns in growth parameter changes in relation to environmental conditions (Alimov, 1981; Bauer, 1992; Ziuganov et al., 1994; Hastie et al., 2000; San Miguel et al., 2004; Dunca et al., 2011; Zotin \& Ieshko, 2017)). In particular, it was demonstrated that the growth constant given by the von Bertalanffy equation is the highest in southernmost $M$. margaritifera populations. It gradually decreases towards higher latitudes to a minimum in northern polar populations (Bauer, 1992).

The comparative descriptions of M. margaritifera individuals are also based on growthrelated parameters of biorhythms, e.g. their period and amplitude. Growth patterns during the M. margaritifera ontogeny were studied previously for populations from the rivers Varzuga (Murmansk region), Keret', Nemina, Kamennaya, Livojoki, Vuokinjoki, and Syuskyanjoki (Karelia) (Zotin, 2009, 2020; Oulasvirta, 2010; Zotin \& Ieshko, 2018, 2020; Zotin et al., 2018, 2020).

Margaritifera margaritifera larvae, called glochidia (singular: glochidium), infect fish gills, and specialise on juvenile salmonids, fry and parr (Meyers \& Millemann, 1977; Young \& Williams, 1984; Bauer, 1988). Spawned glochidia shortly join the drifting plankton and this is when they infest the host fish. As glochidia drift downwards, they come in contact with gills in a passive manner. The descriptions of changes in host gills during glochidial infection are contradictory (Karna \& Millemann, 1978; Bruno et al., 1988). For instance, the adaptive response of gill tissue, mainly the epithelial layer, to glo- chidial infection varies considerably among fish species (Nezlin et al., 1994). The entire cyst formation process takes $9-12 \mathrm{~h}$, but is not synchronous in all glochidia, even inside one host (Nezlin et al., 1994). Once encystment is complete, the glochidium is fully enveloped in the epithelial tissue of the gill. Not all glochidia initially attached to gills become encysted (Nezlin et al., 1994). Approximately $2 \%$ to $5 \%$ of glochidia on gill surface incite no significant response from the nearby epithelial cells and die in one or two days (Nezlin et al., 1994).

A key role in maintaining the $M$. margaritifera abundance is played by the salmonid fish, since glochidia can develop only as parasites on salmonid gills. The main hosts among salmonids are juvenile Salmo salar Linnaeus, 1758 and juvenile $S$. trutta Linnaeus, 1758. However, in the early infection stage fish cast off much of the parasitic larvae, because metamorphosis happens only in $30 \%$ of glochidia on $S$. salar gills, and in $7 \%$ on $\mathrm{S}$. trutta gills ( $\mathrm{Zi}-$ uganov et al., 1994). Research on the role of $S$. trutta and $S$. salar in the M. margaritifera life cycle is a major ecological challenge. What makes these issues even more important is that when working out programmes for the conservation and recovery of extinct $M$. margaritifera populations one needs to know which specific salmonids will ensure that the $M$. margaritifera populations will persist.

The attached $M$. margaritifera larvae begin to metamorphose in autumn. Depending on the ambient conditions, the duration of this process varies and so does the development rate of glochidia. The metamorphosis can take 20-60 days. Otherwise, there is a wintertime diapause (growth and development processes slow down) from which glochidia recover next May or June; then, in summer, metamorphosis is rapidly finalised and a young mussel is formed (Young \& Williams, 1984; Bauer, 1988; Ziuganov et al., 1994). The knowledge of interactions between the host and glochidia is extremely fragmentary, and many questions remain unanswered.

In the host-parasite association, the relationships between $M$. margaritifera glochidia and juvenile salmonids (e.g. S. salar) are highly specialised and adaptive. A high establishment rate and successful metamorphosis of parasitic glochidia are probably enabled by the host low immune status due to an evolution-forged «synchronisation» of the mussel life cycle and 
juvenile $S$. salar wintering, when the fish are the most vulnerable. Such co-existence and coevolution in the studied host-parasite system is a brilliant performance of the Red Queen theory (Van Valen, 1973). The parasitic phase in the $M$. margaritifera life cycle mostly takes place under low temperatures, from October to June, i.e. lasting up to 350 days (Ieshko et al., 2016).

This paper aimed to give a comprehensive description of the status of $M$. margaritifera and its host salmon populations at the source of the Kamennaya lake-river system (River Kem catchment, White Sea drainage basin). The abundance, size and age structure, and growth characteristics of $M$. margaritifera and juvenile $S$. salar populations are assessed in the studied area. We provided data on the infection of juvenile $S$. salar with glochidia and histological analysis of the metamorphosis of encysted $M$. margaritifera larvae parasitising on fish gills. The obtained data could be used as the basis for developing a strategy for the conservation of two endangered species of northern rivers: $M$. margaritifera and $S$. salar.

\section{Material and Methods}

\section{Study area}

The River Kamennaya $\left(64.503181^{\circ} \mathrm{N}\right.$, $\left.30.502156^{\circ} \mathrm{E}\right)$ is located in the northern part of
Karelia (Northwest of European Russia, bordering Finland) and belongs to the basin of the River Kem flowing into the White Sea. The River Kamennaya takes its source from Lake Kamennoe, and flows into Lake Luvozero. Later it passes through several lakes (Kortejarvi, Kimasozero, Nyuk), changing its name several times (Luva, Khame, Rastas, Chirko-Kem), and flows into the River Kem. The River Kamennaya is $75 \mathrm{~km}$ long. Its catchment area is $2510 \mathrm{~km}^{2}$.

Surveys were carried out at the Tsar Porog rapid. The fish fauna in the Tsar Porog rapid area includes S. salar, Cottus gobio Linnaeus, 1758, Perca fluviatilis Linnaeus, 1758, Phoxinus phoxinus Linnaeus, 1758, Lota lota Linnaeus, 1758. The investigated colony of $M$. margaritifera is located in the middle course of the River Kamennaya, below the Tsar Porog rapid (Fig. 1).

The abundance of $M$. margaritifera at the Tsar Porog rapid was studied by underwater observations using light weight diving gear. The grain-size distribution of the bed was evaluated visually, the water velocity was measured by the float method near the water surface, and the depths of the Tsar Porog rapid was detected by standard method using a measuring cord with weight (Studenov, 2000). The mean annual temperature data were taken from CLIMATEDATA.ORG (2020).

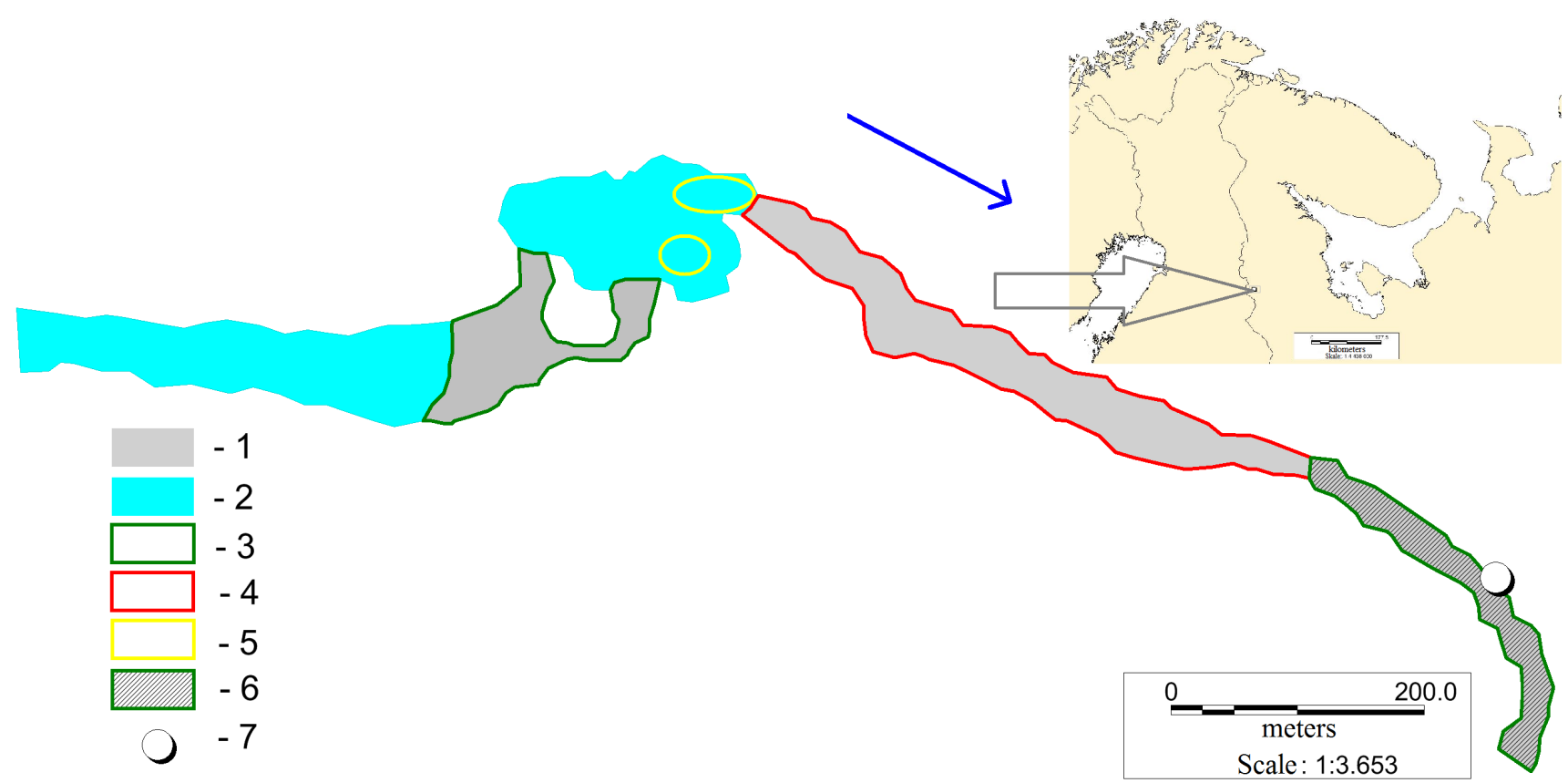

Fig. 1. Map of the Tsar Porog rapid in the River Kamennaya (White Sea drainage basin). Designations: 1 - rapid/riffle stretches; 2 - pools and potholes; 3 - optimal habitats for juvenile Salmo salar; 4 - sites with singular juvenile Salmo salar records; 5 - site inhabited by a Margaritifera margaritifera colony; 6 - site inhabited by Margaritifera margaritifera individuals; 7 - Salmo salar fishing site. 


\section{Growth parameters of Margaritifera margaritifera}

Valves of dead $M$. margaritifera shells were collected from the channel and banks of the River Kamennaya (River Kem catchment, Karelia) to determine the growth parameters of adult M. margaritifera. Altogether, shells of $21 \mathrm{M}$. margaritifera individuals were examined. The outer conchiolin layer of M. margaritifera shells was removed by boiling the valves in $1 \mathrm{M} \mathrm{KOH}$ solution for $10 \mathrm{~min}$. This procedure exposes annual growth rings on the middle prismatic layer. Shell images were taken by scanning with HP ScanJet 5400c (China). The length of each intact annual ring was calculated by using Excel at $0.1 \mathrm{~mm}$ precision.

The growth in mussels is described by the von Bertalanffy (1960) equation:

$$
L_{t}=L_{\infty}\left(1-e^{-k t}\right),
$$

where $L_{t}$ is the annual ring length at age $t ; L_{\infty}$ is the coefficient for the asymptotic length of the shell; $k$ is the growth constant commonly used as the determinant of growth patterns in a specific mussel population. Instead of $k$, we suggest using the recurrent form of the equation above:

$$
\Delta L=-a L_{t}+d,
$$

where $L_{t}$ is the length of annual rings at age $t ; \Delta L$ is the shell length increment in the following year:

$$
a=1-e^{-k} ; d=a L_{\infty},
$$

where $a$ is the constant measuring the rate of growth deceleration, being, essentially, a regression coefficient. Hence, the advantage of recurrent equations over the von Bertalanffy equation is that standard linear regression analysis techniques can be employed to compare growth among both individual mussels and different populations.

The data were approximated by using the von Bertalanffy equation and recurrent equations using Matlab software (v. 7.3.0.267, developed by The MathWorks, Inc, USA). The coefficients of recurrent equations were compared by regression analysis. The applicability of this equation was tested by a nonlinearity criterion (Zotin, 2000). The age dependence of the coefficient $a$ was measured by linear regression analysis (Ivanter \& Korosov, 2010).

The age of mussels $(T)$ was calculated by summing up the age of the first measured annual growth ring $\left(T_{1}\right)$ and the number of annual rings discernible on the shell surface. The age of the first measured annual ring was calculated using the inverse form of the von Bertalanffy equation:

$$
T_{1}=\log _{(1-a)}\left(1-a L_{1} / d\right),
$$

where $L_{1}$ is the length of the first measured annual ring. This age determination technique had to be applied since the apical area of the shell was corroded in almost all the mussels, and a part of the annual rings was undetectable.

The resulting data were smoothed by cubic splines. The time series of the dependence of the relative growth rate $d L /(L d t)$ on annual ring age was calculated using MATLAB software.

Biorhythms were detected by singular spectrum analysis using Caterpillar-SSA software (version 3.40, by GistaT Group, Russia). The option «Centre» was «no». The option «caterpillar length» («window length») was chosen as follows. If there were not more than 24 measurements, the window length was deemed to be one half of the measured annual rings rounded to the nearest integer, otherwise window length was set at 12 . Rhythms with a period below 3 years were regarded as «stochastic noise». The biorhythm period $(P)$ was determined by calculating the mean of the doubled time intervals between successive local extreme points. The biorhythm amplitude $(A)$ was calculated as one half of the difference between the values of successive local extreme points.

The dependence of the biorhythm amplitude $A(t)$ on age $(t)$ was approximated by a hyperbolic equation in Matlab:

$$
A(t)=c /(t+b)
$$

The relationship between the growth parameters of mussels from the River Kamennaya and other previously studied $M$. margaritifera populations and mean annual temperature in the habitat was estimated by the coefficient of correlation. Correlation was deemed absent if the coefficient deviation from 0 was insignificant $(p>0.05)$ (Ivanter \& Korosov, 2010). The statistical distribution of the calculated parameters was tested for normality using the Shapiro-Wilk test (Shapiro \& Wilk, 1965).

\section{Fish infection}

In total, 22 specimens of juvenile $S$. salar were collected from the River Kamennaya stretch below the Tsar Porog rapid to determine the infection with $M$. margaritifera glochidia using the method of complete parasitological dissection (BykhovskayaPavlovskaya, 1985) (Table 1). Salmo salar juveniles from the Tsar Porog rapid were captured by electrical fishing. The fish abundance was determined according to a previously described technique (Zippin, 1956; Bohlin, 1984). 
Table 1. Average total length, body weight values and the rates of glochidial infection in the juvenile Salmo salar from the River Kamennaya

\begin{tabular}{|c|c|c|c|c|c|c|c|}
\hline Salmon age, years & Length, cm & Weight, $\mathrm{g}$ & $\begin{array}{c}\text { Number of the } \\
\text { examined fish }\end{array}$ & Infected fish & Number of glochidia & Intensity & Mean abundance \\
\hline $0+$ & $5.7 \pm 0.2$ & $1.4 \pm 0.2$ & 6 & 5 & 36 & $0-13$ & 6.0 \\
\hline $1+$ & $9.4 \pm 0.9$ & $6.7 \pm 1.8$ & 3 & 3 & 30 & $5-15$ & 10.0 \\
\hline $2+$ & $11.8 \pm 0.5$ & $13.0 \pm 1.4$ & 5 & 5 & 30 & $3-10$ & 6.0 \\
\hline $3+$ & $13.5 \pm 0.6$ & $18.4 \pm 2.4$ & 8 & 7 & 62 & $0-19$ & 7.8 \\
\hline Total & - & - & 22 & 20 & 158 & $0-19$ & 7.2 \\
\hline
\end{tabular}

Fish were caught in autumn, when the water temperature dropped to $1-3^{\circ} \mathrm{C}$. The weight (g) and total length $(\mathrm{cm})$ were measured. The age was determined by scales from below the dorsal fin. The total number of glochidia on gills of the examined fish was counted.

To quantify the infection, prevalence of infection $(E)$ or infection rate $(\%)$ was used according to Bush et al. (1997), as follows:

$$
E=N_{i} / N \times 100,
$$

where $N_{i}$ is the number of infected fish, $N$ is the number of fish examined.

Mean intensity of infection (specimens per fish), or the abundance index $(M)$ was determined as follows:

$$
M=\sum n / N,
$$

where $\sum n$ is the sum of all parasites found on the fish examined.

Statistical analysis of the fish infection indicators and distribution of parasite numbers was carried out using Quantitative Parasitology (QP) software (Rozsa et al., 2000). The glochidial abundance distribution was compared with the negative binomial distribution, using the criterion $\chi^{2}$ :

$$
Y=C_{k+r-1}^{k} p^{r} q^{k} .
$$

\section{Histological analysis of the host gills}

Histological analysis techniques were used to study the growth and development of glochidia on host gills. Gills of $S$. salar parr from the River Kamennaya were dissected from fresh material as soon as possible and then fixed in $10 \%$ formaldehyde. The tissues were embedded in paraffin using MICROM STP-120 spin tissue processor (Thermo fisher scientific, USA). Paraffin moulds of dehydrated and paraffin infiltrated tissues were made using MICROM paraffin embedding centre EC-350 (Thermo fisher scientific, USA). The paraffin moulds were cut on a sliding microtome MICROM HM 450 (Thermo fisher scientific, USA) in transverse sections at $6 \mu \mathrm{m}$ thickness. The sections were stained with haematoxylin and eosin (H \& E) using the manual specifying container lines (BioOptica, Italy). Histological sections were studied under the light microscope Olympus CX41 (Olympus, Japan) with eye lens $\times 10$ and objective lenses $\times 5, \times 10, \times 20, \times 40, \times 100$. The sections on the slides were photographed with Olympus SC50 camera (Olympus, Japan) connected to the microscope. All photos were analysed with CellSens software (Olympus, Japan). For the histological part of the study, we used recommendations and advice of Mikodina et al. (2009). The dimensional characteristics of glochidia were measured according to the methodology developed by Murzina et al. (2017). The following parameters were measured in glochidia: length (distance from the hinge to the opposite edge of the shell), width (distance between the lateral edges of the shell), convexity (distance between the most distant points between the shell valves) (Fig. 2), elongation (larva length to width ratio).

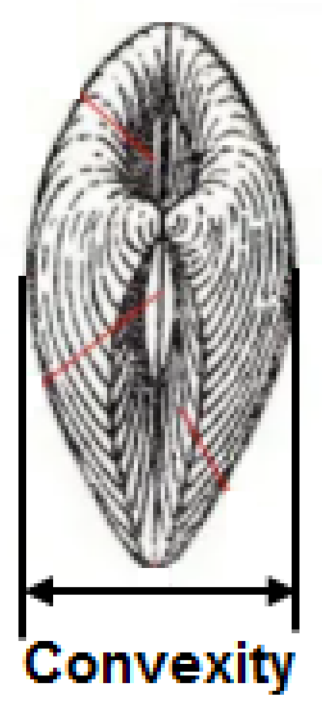

Fig. 2. Measurement of convexity in a glochidium. 
The parameters measured in cysts were the largest size, the smallest size, elongation (the ratio of the largest and the smallest sizes), the wall thickness along the major axis (half the difference between the largest cyst size and glochidium length), the wall thickness along the minor axis (half the difference between the smallest cyst size and glochidium width). The morphology and dimensional characteristics of parasitic glochidia from the River Kamennaya were compared with similar results obtained previously for the River Vuokinjoki (a tributary of Lake Verkhnee Kuito, River Kem catchment, White Sea drainage basin) during the first ten days of October (Ieshko et al., 2016). The difference significance of glochidial sizes was estimated using one-way analysis of variance (ANOVA) in Statgraphics for Windows 2.5.

\section{Results}

Characteristics of the habitats of Margaritifera margaritifera and juvenile Salmo salar

The colony of $M$. margaritifera approximately comprises 400-500 specimens. It occupies the lower part of the Tsar Porog rapid area (Fig. 1). Mussels were distributed over an area of $150-200 \mathrm{~m}^{2}$. The depths in this section are 1.5-4.0 m. The current velocity of the streaming water is $0.3-0.5 \mathrm{~m} / \mathrm{s}$. Margaritifera margaritifera can be found in pebble-gravel bed (with sand) singly or in small groups. No shells were found above, in the Tsar Porog rapid itself.

The area inhabited by young Salmo salar is situated $500 \mathrm{~m}$ below the $M$. margaritifera colony at the Tsar Porog rapid. The depth is $0.3-0.7 \mathrm{~m}$ and the flow rate is $0.7-1.2 \mathrm{~m} / \mathrm{s}$ (Fig. 1). The juveniles studied in October 2018 were mainly represented by $0+$ and $3+$ fish.

\section{Growth parameters of adult Margariti- fera margaritifera}

The main linear individual growth trend in $M$. margaritifera specimens is closely modeled by the von Bertalanffy equation. An example of data approximation by means of this equation is given in Fig. 3a. The values of the coefficients of von Bertalanffy and recurrent equations, individual size, age and growth characteristics of molluscs are given in Table 2.

In the recurrent equation which specifies growth deceleration, coefficient $a$ varies widely among specimens (0.048 to 0.100$)$, and differs significantly from one another $(p<0.001)$. The statistical distribution composed of the values of coefficient $a$ is normal according to the Shapiro-Wilk test. The mean value of this distribution, $0.076 \pm 0.003$, can, therefore, be used for comparing coefficient $a$ in different $M$. margaritifera populations.
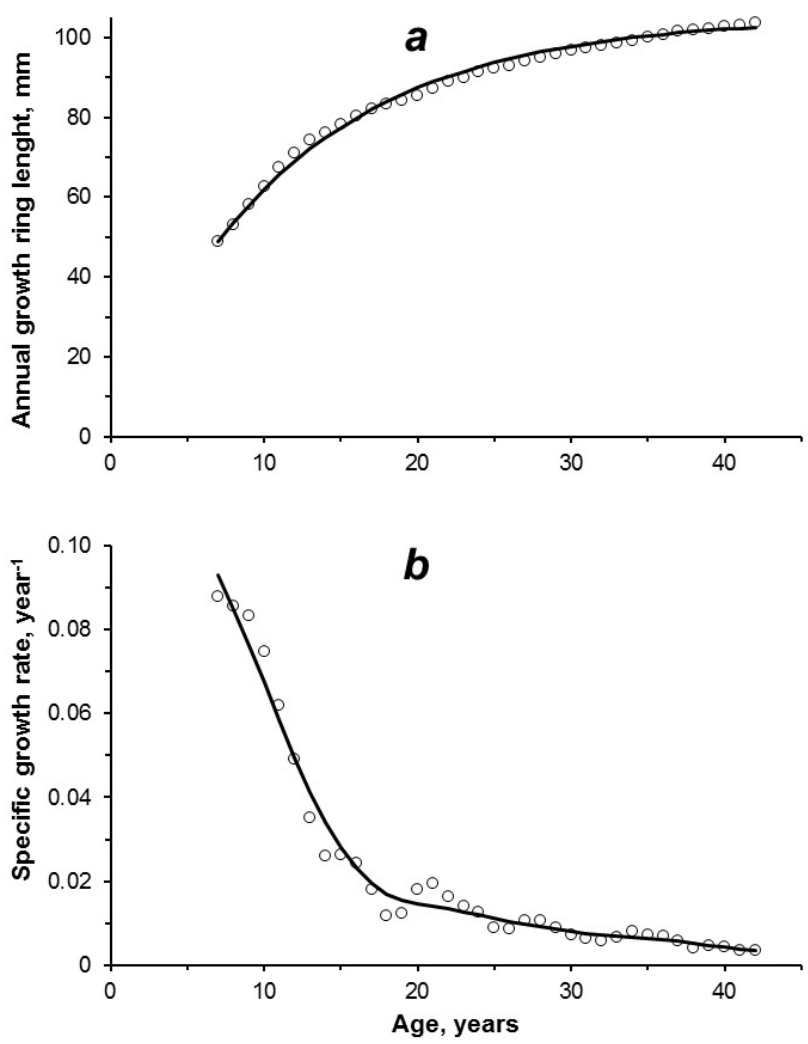

Fig. 3. Growth parameters of Margaritifera margaritifera in the study area. Designations: a - example of linear growth in Margaritifera margaritifera (specimen 3). Circles indicate experimental data; the line is an approximation by the von Bertalanffy equation; $b$-Age dependence of the relative linear growth rate in Margaritifera margaritifera. (specimen 3). Circles indicate calculated values; the line is a smoothing by cubic splines.

The growth deceleration coefficient $a$ in the recurrent equation tends to decrease with $M$. margaritifera age $(T)$. The regression coefficient of the relationship $a(T)$ is $-0.61 \pm 0.3210^{-3}$ year $^{-1}(n=21)$. However, the deviation of this coefficient from 0 is insignificant.

Noteworthy are the extremely low values of growth in comparison with the length of M. margaritifera individuals (Table 2). This is due to the fact that these individuals grow relatively rapidly. Their growth rate is typical for the southernmost $M$. margaritifera populations.

A singular spectrum analysis shows that the main trends of change in shell size practically coincide with the curve drawn after approximation by the von Bertalanffy growth equation for all the investigated specimens. The existence of biorhythms accompanying the main trend is obvious after the kinetics analysis of the relative growth rate in the M. margaritifera individual development (Fig. 3b).

The biorhythms are highlighted after the excretion of wave components by singular spectrum analysis (Fig. 4). A majority of individuals characterised by three regular biorhythms with different frequencies of oscillations (Table 3, Fig. 4). 
Table 2. Individual size, age and growth characteristics of Margaritifera margaritifera from the River Kamennaya

\begin{tabular}{|c|c|c|c|c|c|c|c|}
\hline Specimen No. & $n$ & $L, \mathrm{~mm}$ & $T$, year & $a$ & $d, \mathrm{~mm}$ & $k$, year & $L_{\infty}, \mathrm{mm}$ \\
\hline 1 & 35 & 110.2 & 47 & $0.048 \pm 0.006$ & $5.8 \pm 0.5$ & $0.049 \pm 0.006$ & $121.5 \pm 3.8$ \\
\hline 2 & 22 & 122.1 & 36 & $0.051 \pm 0.005$ & $7.4 \pm 0.5$ & $0.053 \pm 0.006$ & $143.4 \pm 4.0$ \\
\hline 3 & 11 & 86.9 & 16 & $0.052 \pm 0.018$ & $8.0 \pm 1.0$ & $0.053 \pm 0.019$ & $154.0 \pm 24.3$ \\
\hline 4 & 13 & 92.0 & 17 & $0.063 \pm 0.011$ & $8.7 \pm 0.7$ & $0.065 \pm 0.012$ & $137.8 \pm 11.1$ \\
\hline 5 & 11 & 85.5 & 15 & $0.068 \pm 0.017$ & $9.0 \pm 1.0$ & $0.071 \pm 0.018$ & $131.4 \pm 14.2$ \\
\hline 6 & 21 & 103.4 & 27 & $0.068 \pm 0.007$ & $8.3 \pm 0.5$ & $0.071 \pm 0.007$ & $121.7 \pm 3.8$ \\
\hline 7 & 23 & 103.6 & 30 & $0.070 \pm 0.006$ & $8.2 \pm 0.5$ & $0.072 \pm 0.006$ & $117.5 \pm 3.0$ \\
\hline 8 & 13 & 97.8 & 17 & $0.070 \pm 0.011$ & $9.7 \pm 0.7$ & $0.072 \pm 0.012$ & $138.3 \pm 10.0$ \\
\hline 9 & 4 & 61.0 & 8 & $0.076 \pm 0.071$ & $10.1 \pm 2.7$ & $0.079 \pm 0.080$ & $133.1 \pm 46.0$ \\
\hline 10 & 19 & 98.4 & 25 & $0.076 \pm 0.007$ & $8.7 \pm 0.5$ & $0.079 \pm 0.007$ & $115.0 \pm 3.3$ \\
\hline 11 & 21 & 104.9 & 28 & $0.077 \pm 0.007$ & $9.2 \pm 0.6$ & $0.081 \pm 0.008$ & $118.4 \pm 3.0$ \\
\hline 12 & 15 & 93.6 & 20 & $0.079 \pm 0.009$ & $9.2 \pm 0.6$ & $0.082 \pm 0.009$ & $116.9 \pm 4.8$ \\
\hline 13 & 25 & 105.5 & 28 & $0.081 \pm 0.007$ & $9.5 \pm 0.6$ & $0.084 \pm 0.008$ & $118.0 \pm 3.0$ \\
\hline 14 & 20 & 10.8 & 24 & $0.084 \pm 0.006$ & $9.6 \pm 0.5$ & $0.088 \pm 0.007$ & $114.1 \pm 2.6$ \\
\hline 15 & 17 & 91.3 & 21 & $0.085 \pm 0.008$ & $9.2 \pm 0.5$ & $0.088 \pm 0.009$ & $108.2 \pm 3.5$ \\
\hline 16 & 35 & 104.0 & 43 & $0.085 \pm 0.005$ & $9.0 \pm 0.4$ & $0.089 \pm 0.006$ & $105.0 \pm 1.0$ \\
\hline 17 & 12 & 86.4 & 17 & $0.086 \pm 0.012$ & $9.6 \pm 0.8$ & $0.090 \pm 0.013$ & $111.5 \pm 5.5$ \\
\hline 18 & 12 & 91.2 & 16 & $0.095 \pm 0.013$ & $10.9 \pm 0.9$ & $0.099 \pm 0.015$ & $115.2 \pm 5.9$ \\
\hline 19 & 14 & 92.2 & 19 & $0.095 \pm 0.009$ & $10.4 \pm 0.6$ & $0.100 \pm 0.010$ & $109.0 \pm 3.5$ \\
\hline 20 & 16 & 96.4 & 19 & $0.098 \pm 0.010$ & $11.0 \pm 0.7$ & $0.103 \pm 0.011$ & $112.6 \pm 4.0$ \\
\hline 21 & 7 & 77.2 & 10 & $0.100 \pm 0.027$ & $11.8 \pm 1.4$ & $0.105 \pm 0.031$ & $118 \pm 14.2$ \\
\hline
\end{tabular}

Note: $n$-number of measured annual rings; $L$ - shell length; $T$ - mussel age; $a, d$-coefficients of recurrent equation; $k, L_{\infty}-$ coefficients of von Bertalanffy equation.

Table 3. Growth parameters in different Margaritifera margaritifera populations

\begin{tabular}{|c|c|c|c|c|c|c|}
\hline River (latitude, $t^{\circ} \mathrm{C}$ ) & $a$ & $k$, year ${ }^{-1}$ & $g, 10^{-3}$ year $^{-1}$ & $P_{1}$, year & $P_{2}$, year & $P_{3}$, year \\
\hline Kamennaya $\left(64.4^{\circ} \mathrm{N}, 0.7\right)$ & $\begin{array}{c}0.076 \pm 0.003 \\
(n=21)\end{array}$ & 0.080 & $\begin{array}{c}-0.61 \pm 0.32 * \\
(n=21)\end{array}$ & $\begin{array}{c}11.5 \pm 0.7 \\
(n=15)\end{array}$ & $\begin{array}{l}6.4 \pm 0.2 \\
(n=19)\end{array}$ & $\begin{array}{l}4.0 \pm 0.1 \\
(n=20)\end{array}$ \\
\hline Syuskyanjoki (above the dam) $\left(61.7^{\circ} \mathrm{N}, 4.9\right)$ & $\begin{array}{c}0.114 \pm 0.003 \\
(n=88)\end{array}$ & 0.121 & $\begin{aligned}-1.78 & \pm 0.27^{* *} \\
(n & =56)\end{aligned}$ & $\begin{array}{c}13.8 \pm 0.7 \\
(n=44)\end{array}$ & $\begin{array}{l}6.0 \pm 0.1 \\
(n=81)\end{array}$ & $\begin{array}{r}4.0 \pm 0.1 \\
(n=88) \\
\end{array}$ \\
\hline Nemina $\left(62.8^{\circ} \mathrm{N}, 2.3\right)$ & $\begin{array}{c}0.064 \pm 0.005 \\
(n=23)\end{array}$ & 0.066 & $\begin{array}{c}0.17 \pm 0.30^{*} \\
(n=23)\end{array}$ & $\begin{array}{c}12.6 \pm 0.8 \\
(n=21)\end{array}$ & $\begin{array}{l}6.4 \pm 0.2 \\
(n=23)\end{array}$ & $\begin{array}{c}4.0 \pm 0.1 \\
(n=23)\end{array}$ \\
\hline Livojoki $\left(64.8^{\circ} \mathrm{N}, 0.7\right)$ & $\begin{array}{c}0.060 \pm 0.006 \\
(n=32)\end{array}$ & 0.062 & $\begin{array}{c}-0.52 \pm 0.41^{*} \\
(n=32)\end{array}$ & $\begin{array}{c}13.8 \pm 1.2 \\
(n=21)\end{array}$ & $\begin{array}{l}6.2 \pm 0.2 \\
(n=28)\end{array}$ & $\begin{array}{c}4.0 \pm 0.1 \\
(n=29)\end{array}$ \\
\hline Vuokinjoki $\left(64.9^{\circ} \mathrm{N}, 0.7\right)$ & $\begin{array}{c}0.060 \pm 0.006 \\
(n=57)\end{array}$ & 0.062 & $\begin{aligned}-0.63 & \pm 0.07 * * \\
(n & =57)\end{aligned}$ & $\begin{array}{c}13.3 \pm 0.5 \\
(n=39)\end{array}$ & $\begin{array}{l}6.4 \pm 0.2 \\
(n=49) \\
\end{array}$ & $\begin{array}{r}4.0 \pm 0.1 \\
(n=57) \\
\end{array}$ \\
\hline Keret' $\left(66.0^{\circ} \mathrm{N}, 0.1\right)$ & $\begin{array}{c}0.061 \pm 0.002 \\
(n=11)\end{array}$ & 0.063 & $\begin{array}{c}-0.28 \pm 0.17 * \\
(n=11)\end{array}$ & $\begin{array}{c}13.8 \pm 1.5 \\
(n=8) \\
\end{array}$ & $\begin{array}{c}6.8 \pm 0.4 \\
(n=11)\end{array}$ & $\begin{array}{r}4.0 \pm 0.1 \\
(n=11) \\
\end{array}$ \\
\hline Varzuga $\left(66.7^{\circ} \mathrm{N}, 0.8\right)$ & $\begin{array}{c}0.048 \pm 0.001 \\
(n=90)\end{array}$ & 0.049 & $\begin{array}{c}0.02 \pm 0.09^{*} \\
(n=90)\end{array}$ & $\begin{array}{c}13.4 \pm 0.1 \\
(n=50)\end{array}$ & $\begin{array}{c}6.8 \pm 0.1 \\
(n=84)\end{array}$ & $\begin{array}{c}4.0 \pm 0.1 \\
(n=90)\end{array}$ \\
\hline
\end{tabular}

Note: $t^{\circ} \mathrm{C}$ - mean annual temperature; $a$ - growth deceleration coefficient from recurrent equation; $k$ - growth constant from von Bertalanffy equation; $g$ - coefficient of regression of the age-dependence of $a ; n$ - number of specimens per sample; $P_{1}-$ period of low-frequency biorhythms; $P_{2}$ - period of medium-frequency biorhythms; $P_{3}$ - period of high-frequency biorhythms; ${ }^{*}$ - deviation from 0 is insignificant $(\mathrm{p}>0.05) ; * *-$ deviation from 0 is significant $(p<0.001)$.

For the first time, growth parameters of $M$. margaritifera populations in the River Kamennaya have been studied. Data on the growth parameters of $M$. margaritifera populations from other rivers were obtained previously (Zotin, 2009, 2020; Zotin \& Ieshko, 2018, 2020; Zotin et al., 2018, 2020).

In some cases, the $M$. margaritifera individuals were not old enough for measuring the number of annual rings for identification of lowfrequency biorhythms. The periods of each of the biorhythms showed no significant variation either through the ontogeny of individual specimens or among individuals. The oscillation frequen- cy averaged over the entire mussel sample was $11.5 \pm 0.7$ years for low-frequency biorhythms $(\mathrm{n}=15), 6.4 \pm 0.2$ years for medium-frequency biorhythms $(n=19), 4.0 \pm 0.1$ years for high-frequency biorhythms $(n=20)$.

The biorhythms with periods of 11.5 years and 6.4 years are decaying. The age-related decrease in sample-averaged amplitude of these biorhythms can be modelled by hyperbolic dependence $A(t)$ with identical coefficients (Fig. 5): $c=0.05 \pm 0.01$, $b=8.4 \pm 3.2$ years $(n=18)$. Biorhythms with the 4-year period have a constant amplitude at an average of $0.65 \pm 0.10 \mathrm{kY}^{-1}(n=14)$. 

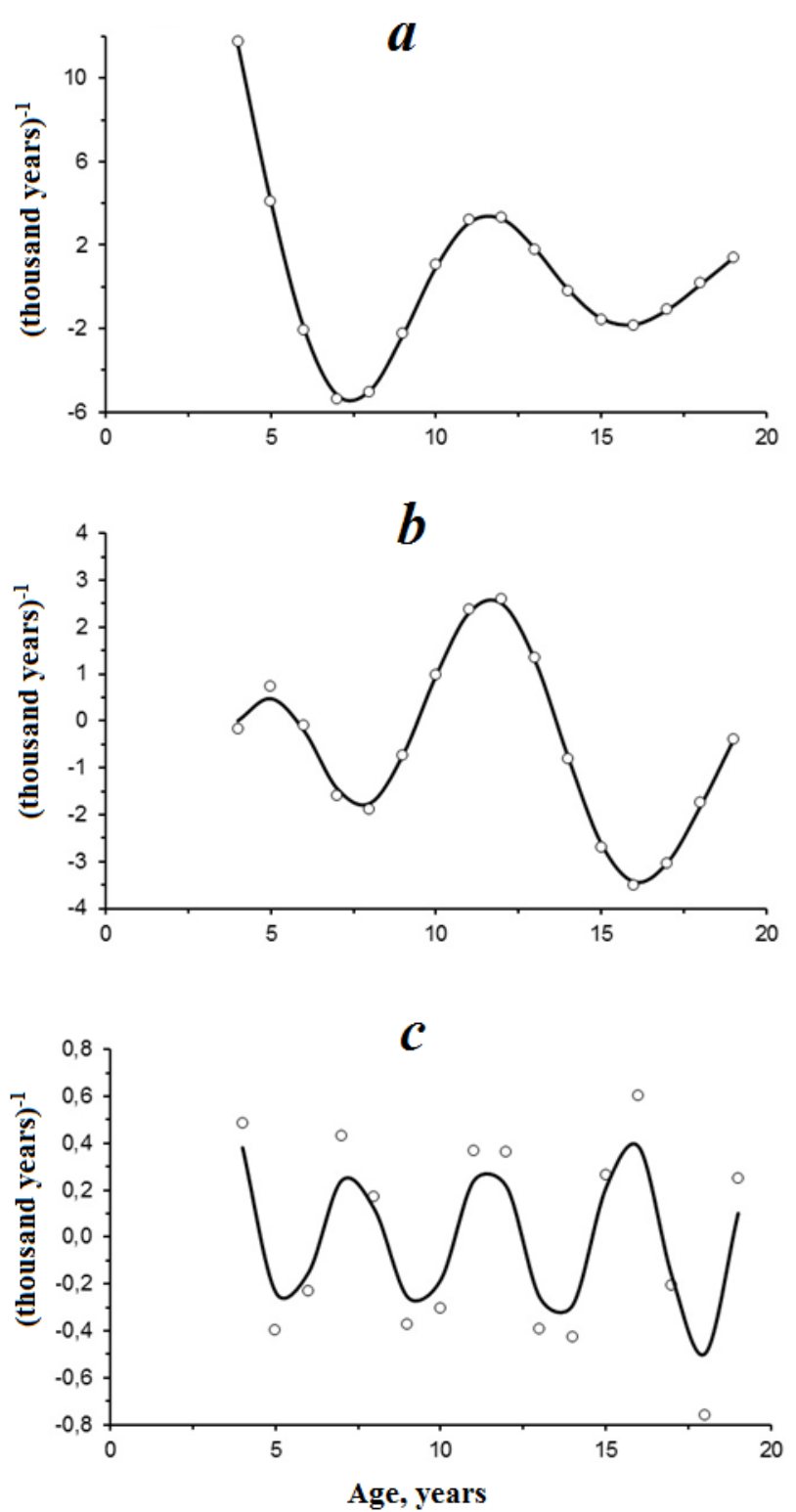

Fig. 4. Example of biorhythms in the relative rate of the Margaritifera margaritifera individual linear growth (specimen 12). Designations: a - biorhythm with ca. 11.5 year period; $b$ - biorhythm with ca. 6.4 year period; c - biorhythm with ca. 4.0 year period; circles indicate the calculated values, lines are smoothing by cubic splines.

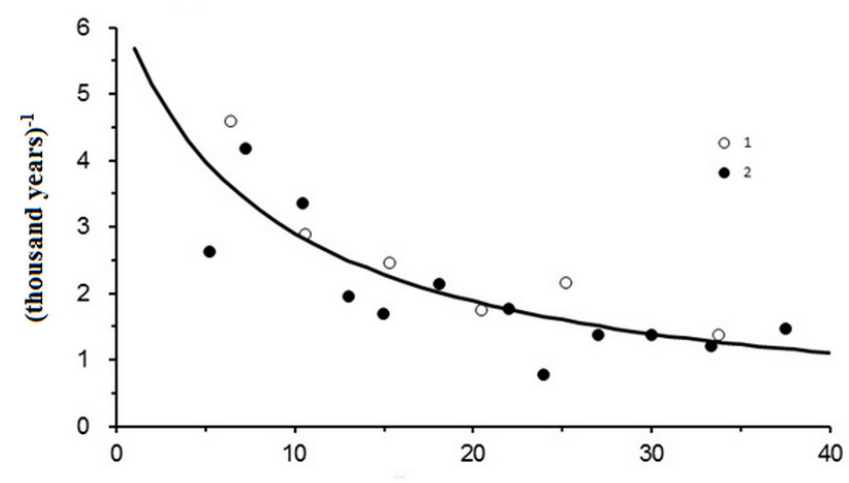

Age, years

Fig. 5. Age dependence of the amplitude of mussel growth biorhythms. Designations: 1 - biorhythm with ca. 11.5-year period, 2 - biorhythm with ca. 6.4-year period; Line indicates approximation by hyperbolic dependence $A(t)$.

\section{Characteristics of parasitic glochidia}

The infection intensity in juveniles was relatively low (Table 1). The distribution of glochidial abundance in the juvenile population follows the negative binomial law according to the $\chi^{2}$ criterion. The values of the negative binomial distribution parameter $k=2.25$ correspond to a uniform distribution of encysted glochidia on the gills of $S$. salar juveniles of different ages and demonstrate a stable state of the host-parasite relationship. Almost all the examined fish were infected (prevalence is $90.9 \%$ ) (Table 1). The fish in the samples were underyearlings (at $0+$ age), i.e. the age group of $S$. salar infected by glochidia for the first time. Another age group was parr, which had already been infected by glochidia last year. Interestingly, there was no significant correlation between the intensity of the glochidial infection and the size or body weight of the host fish. The Spearmen coefficient of correlation between the fish length and the number of glochidia was $r=-0.07(p=0.75)$, and for the weight of fish: $r=-0.05(p=0.82)$.

Microscopic analysis of glochidia from secondary lamellae of $S$. salar showed that a cyst had already formed around all $M$. margaritifera larvae in the first ten days of October (Fig. 6). The shape of glochidia was mostly oval. Glochidia with the smallest length and width parameters $(46.4 \mu \mathrm{m}$ and $34.8 \mu \mathrm{m}$, respectively) were found to have a rounded shape (Table 4).

The average glochidium length was $64.3 \mu \mathrm{m}$, the width was $44.0 \mu \mathrm{m}$. These parameters indicate that the size of parasitic larvae slightly exceeds the ca. $50 \mu \mathrm{m}$ size of free-living glochidia (Ziuganov et al., 1994). It means that the process of glochidial growth has just begun.

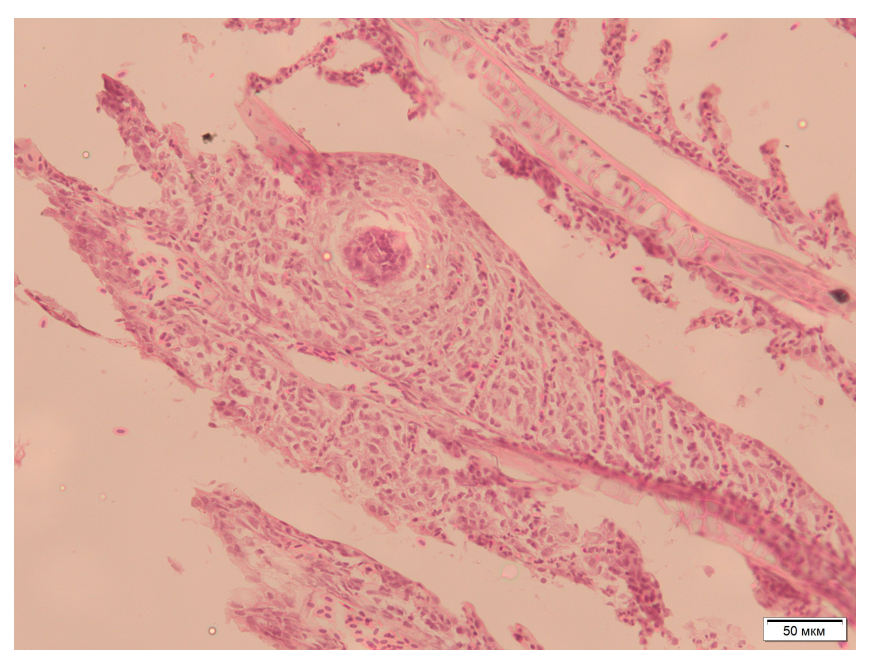

Fig. 6. Glochidium surrounded by a cyst on the gills of Salmo salar from the River Kamennaya in early October. Staining: haematoxylin and eosin; magnification: $\times 20$; scale: $50 \mu \mathrm{m}$. 
The elongation of glochidia is an indicator of morphogenesis. Its average value was 1.5. This parameter is 1.8 for glochidia with a maximum length $(110.1 \mu \mathrm{m})$, pointing to an onset of metamorphosis in some glochidia (Fig. 7). Probably, they attached to the gills earlier than others.

According to the size of glochidia, it is most likely that the $S$. salar got infested by $M$. margaritifera larvae within the previous 30 days. All glochidia found attached to secondary gill lamellae were viable, since nucleoli were visualised in the cells of the larval mantle. Their presence is known to indicate a series of metabolic processes. Structures such as cells of the outer and inner larval mantle, as well as the adductor could be clearly seen in all glochidia on $S$. salar. The $M$. margaritifera larvae on secondary lamellae of $S$. salar gills were generally found along the entire lamella length. The infection rate was very low. Interestingly, some glochidia developed within one joint cyst. Such larvae had a non-standard elongated shape (strongly elongated along the gill lamellae) and were larger.

The parameters of the cyst wall thickness along the larger and smaller axes are of particular importance in assessing the readiness of glochidia for wintering and transition to the state of diapause (Murzina et al., 2017), wherefore the necessary measurements were taken. The average values were $45.0 \mu \mathrm{m}$ and $23.0 \mu \mathrm{m}$, respectively (Table 5).

The thickest cyst walls were found in the largest glochidia $(237.0 \mu \mathrm{m}$ and $110.0 \mu \mathrm{m}$, respectively). However, some of the largest cysts on $S$. salar gills had an irregular shape, strongly elongated along the lamella. The elongation of such cysts was up to 2.4 .

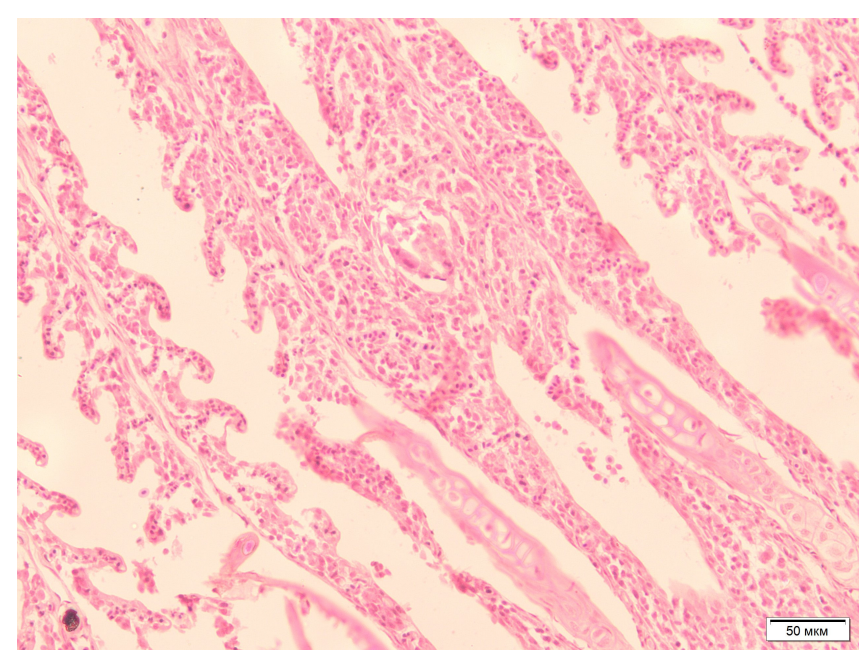

Fig. 7. Glochidium in a cyst formed by secondary lamellae of two adjacent primary lamellae in Salmo salar. Staining: haematoxylin and eosin; magnification: $\times 20$; scale: $50 \mu \mathrm{m}$.

The variation in values of the larval cyst size indicates that the glochidia are in different developmental stages. The cyst formation is caused by the migration of the host epithelial cells of secondary gill lamellae, which finally envelope the glochidium in a multilayer formation. A small number of glochidia ( 4 out of 30 glochidia, or $0.13 \%$ of the total number measured) were in the «non-growing glochidia» stage in October. Such larvae are surrounded by a thin cyst formed by an inclusion of the nearest gill lamellae. No visible changes in the structure of cysts at this stage are known to occur (usually within the first 15 days after infestation) (Nezlin et al., 1994). The other 26 glochidia $(0.87 \%$ of the total number measured) were enclosed in larger cysts. This indicates that the infestation happened more than 20 days before, and the glochidia were in the initial stage of metamorphosis (Nezlin et al., 1994). However, two sites on gill tissue had signs of damage or disruption due to glochidia drop-off or attachment failure.

Table 4. Dimensions of Margaritifera margaritifera glochidia on Salmo salar gills

\begin{tabular}{|l|c|c|c|c|}
\hline \multicolumn{1}{|c|}{ River } & Length, $\mu \mathrm{m}$ & Width, $\mu \mathrm{m}$ & Convexity, $\mu \mathrm{m}$ & Elongation \\
\hline \multirow{2}{*}{ Kamennaya } & $64.3 \pm 6.8$ & $44.0 \pm 2.5$ & $44.4 \pm 3.7$ & $1.46 \pm 0.10$ \\
& $(46.4-110.1)$ & $(34.8-63.4)$ & $(31.3-71.9)$ & $(1.09-2.40)$ \\
\hline Vuokinjoki & $84.5 \pm 2.8^{*}$ & $65.8 \pm 2.3 * *$ & $70.0 \pm 3.2^{* *}$ & $1.33 \pm 0.05$ \\
\hline
\end{tabular}

Note: The significance of parameter differences between the two rivers: $*-p<0.05$; $* *-p<0.001$; the range of variation is given in brackets.

Table 5. Dimensions of Margaritifera margaritifera glochidia cysts on Salmo salar gills

\begin{tabular}{|l|c|c|c|c|c|}
\hline \multicolumn{1}{|c|}{ River } & $L_{\max }, \mu \mathrm{m}$ & $L_{\min }, \mu \mathrm{m}$ & $E$ & $T_{\max }, \mu \mathrm{m}$ & $T_{\min }, \mu \mathrm{m}$ \\
\hline Kamennaya & $143.5 \pm 10.1$ & $90.7 \pm 4.4$ & $1.59 \pm 0.09$ & $44.59 \pm 4.72$ & $23.1 \pm 2.6$ \\
\hline Vuokijoki & $178.7 \pm 5.5^{* *}$ & $136.6 \pm 3.2^{* * *}$ & $1.32 \pm 0.05^{*}$ & $46.62 \pm 2.29$ & $36.1 \pm 1.5^{* * *}$ \\
\hline
\end{tabular}

Note: $L_{\max }-$ maximum size; $L_{\min }-$ minimum size; $E$ - elongation; $T_{\max }-$ wall thickness along the major axis; $T_{\min }-$ wall thickness along the minor axis; the significance of parameter differences between the rivers: ${ }^{*}-p<0.05 ; * *-p<0.01 ; * * *-p<0.001$. 


\section{Discussion}

The River Kamennaya system is the upper section of the Kem River catchment (White Sea drainage basin). Lake Kamennoe, from which the River Kamennaya originates, lies at 199 m a.s.l. The fish species occurring in the river rapids are Cottus gobio, Perca fluviatilis, Phoxinus phoxinus, Lota lota. The River Kamennaya mouth is inhabited by Esox lucius Linnaeus, 1758. No juvenile $S$. trutta has been encountered. So, S. salar is believed to be the only intermediate host for M. margaritifera in the River Kamennaya. Hence, well-being of the $S$. salar population is a precondition for the survival of the M. margaritifera colonies in the Kostomuksha State Nature Reserve.

\section{Margaritifera margaritifera age and growth}

The measure commonly used to describe growth in bivalves is the so-called growth constant $(k)$, derived from the von Bertalanffy equation (Alimov, 1981; Bauer, 1992; Ziuganov et al., 1994). We preferred using another constant instead, which we have termed the growth deceleration coefficient $(a)$, and which is related to the growth constant as $a=1-\exp (-k)$. Here, if $k$ is near 0 , then the coefficients $a$ and $k$ are roughly equal. The advantages of using the coefficient $a$ instead of the growth constant $k$ are that this coefficient is distributed normally, and it is included in the recurrent form of the recurrent equation as a regression coefficient. Hence, it is suitable for comparisons based on standard regression analysis techniques.

The average values of the coefficient $a$ for M. margaritifera surveyed was 0.076 , and hence $k=0.080$. According to the literature (Alimov, 1981; Bauer, 1992; Ziuganov et al., 1994; Hastie et al., 2000; San Miguel et al., 2004; Dunca et al., 2011; Zotin \& Ieshko, 2017), the growth constant $k$ can vary among populations within a range of $0.02-0.11$. Thus, the value of the growth constant for the River Kamennaya population is close to the average value for $M$. margaritifera.

Table 3 provides data on growth parameters in several $M$. margaritifera populations analysed in this study and by Zotin, 2009, 2020; Zotin \& Ieshko, 2018, 2020; Zotin et al., 2018, 2020. The M. margaritifera populations in the rivers Livojoki, Vuokinjoki and Kamennaya, belonging to the River Kem catchment, demonstrate a similar trend for the coefficient $a$ to decrease with age $(T)$. We attribute this to the construction and operation of Kem hydropower plants from 1962 to
1993, which altered the hydrological conditions in the River Kem catchment (Zotin et al., 2020). By corroborating this hypothesis, the population in the River Syuskyanjoki, where the hydrological conditions have also changed after the dam demolition in 1989, also exhibited a clear $a(T)$ correlation. Meanwhile, no such relationship is observed for populations in the rivers Varzuga, Keret', and Nemina, where the hydrological conditions have not been altered (Table 3 ).

Table 3 also suggested that the growth deceleration coefficient $a$ in different $M$. margaritifera populations tends to decrease as the mean annual temperature $\left(t^{\circ}\right)$ in the habitat increases. The correlation ratio $\eta\left(a / t^{\circ}\right)=0.93 \pm 0.17$ is significantly different from $0(p<0.01)$. No such relationship is observed for the average period of any of the three biorhythms.

However, in contrast to other biorhythms, for biorhythms with an average period $P_{2}$ a regression analysis shows that the relationship between the period of this biorhythm and the latitude of the habitat $L_{a}$ for all populations (Table 3 ) is described by the linear equation $P_{2}=0.16$ ( year $\left./{ }^{\circ} \mathrm{N}\right) \times L_{a}-3.9$ (year). The difference of the regression coefficient from 0 is reliable $(p<0.01)$. This indicates that the value of the period with the average frequency depends on the habitat conditions of the $M$. margaritifera.

Modern thermodynamics claims that a characteristic trait of nonlinear dissipative structures, including living systems, is the existence of several stationary states (Zotin, 2009, 2014). The tendency toward each stationary state is accompanied by one and only one decaying rhythm with a certain characteristic time. When in stationary state, the rhythm amplitude becomes stable (Prigogine, 1972; Malek-Mansour et al., 1980).

The low-frequency biorhythm with a period of 11.5 years is similar to the growth biorhythm in the marine bivalve Crenomytilus grayanus, with a period of 10-15 years (Zolotarev, 1974). Zolotarev (1974) believes these rhythms are exogenous and mediated by 11-year solar cycles.

The other two biorhythms appear to be endogenous, unrelated to external periodic processes. They may probably be rooted in thermodynamic regularities. The medium-frequency biorhythm is presumably connected with the organism's tendency towards the final stationary state, wherefore it decays throughout the ontogeny. The biorhythm with the constant 4-year period probably arises from the current stationary 
state the biological system remains in over its lifetime if the environment is invariable (Zotin, 2009; Zotin \& Kleimenov, 2013). The constancy of the amplitude in this case supposedly evidences that the current stationary state is due to $M$. margaritifera genetic traits, rather than the effect of external factors.

It is possible that the biorhythms we have detected are of a different, purely biological nature. For instance, they may result from the organism's response to periodic processes in the environment of which we are unaware. A definitive answer requires more studies with more populations and also with other species.

\section{The infection and metamorphosis of en- cysted glochidia}

The habitation of $S$. salar juveniles at $500 \mathrm{~m}$ below the Tsar Porog rapid probably determines the observed features of the glochidial infection. Considering the high fecundity of M. margaritifera (up to 3000000 larvae per female), which release a huge amount of glochidia downstream, almost all of the studied $S$. salar juveniles were infected $(90.9 \%)$, regardless of age. Nevertheless, the intensity of the infection in juveniles was low, ranging from 1 to 19 glochidia per fish. A relatively low level of infection in juveniles is probably associated with a high distance from the donor M. margaritifera colony. It should be noted that for the River Vuokinjoki, where $S$. salar parr live in close proximity to adult mussels, the average number of glochidia was 48.6, varying from 1 to 274 (Ieshko et al., 2016).

A comparative analysis of the dimensional characteristics of glochidia attached to the gills of $S$. salar from the River Kamennaya and the River Vuokinjoki in the first ten days of October showed that indices of the growth and development of glochidia such as their length, width, convexity and elongation were significantly lower in $M$. margaritifera larvae from the River Kamennaya in comparison with those from the River Vuokinjoki (Ieshko et al., 2016). These differences can probably be explained by different temperature conditions in these rivers. So, an earlier transition across the water temperature threshold of $10^{\circ} \mathrm{C}$ in the River Vuokinjoki is considered as a «transition» in M. margaritifera's life cycle, which corresponds to the onset of the parasitic phase in M. margaritifera. Thus, it can be assumed that juvenile $S$. salar from the River Vuokinjoki were infected with glochidia earlier. The values of the parameter «elongation» indicate a more active and prolonged metamorphosis of glochidia from the River Vuokinjoki compared with those from the River Kamennaya. Margaritifera margaritifera larvae are known to change their shape from rounded to more elongate during the metamorphosis process (Zotin, 2009). The cyst wall thickness along the smaller axis differs significantly for $S$. salar juveniles from the studied rivers, which gives reason to regard this parameter as an indicator of glochidial development.

A comparative analysis of the size characteristics of larvae attached to $S$. salar gills from the River Kamennaya and River Vuokinjoki in the first ten days of October was carried out to assess the characteristics of the glochidia developmental stages. Both rivers belong to the White Sea basin, but the River Vuokinjoki is located farther north $\left(64.9^{\circ} \mathrm{N}\right)$ than the River Kamennaya $\left(64.4^{\circ} \mathrm{N}\right)$. The indices of glochidia growth and development (length, width, convexity and elongation) were significantly lower in M. margaritifera larvae from the River Kamennaya in comparison with those from the River Vuokinjoki. Glochidia from the River Kamennaya and from the River Vuokinjoki had a similar oval shape (Fig. 6, Fig. 8). However, such parameters as the length, width and convexity of M. margaritifera larvae from the River Vuokinjoki were on average $31.7 \%$ higher.

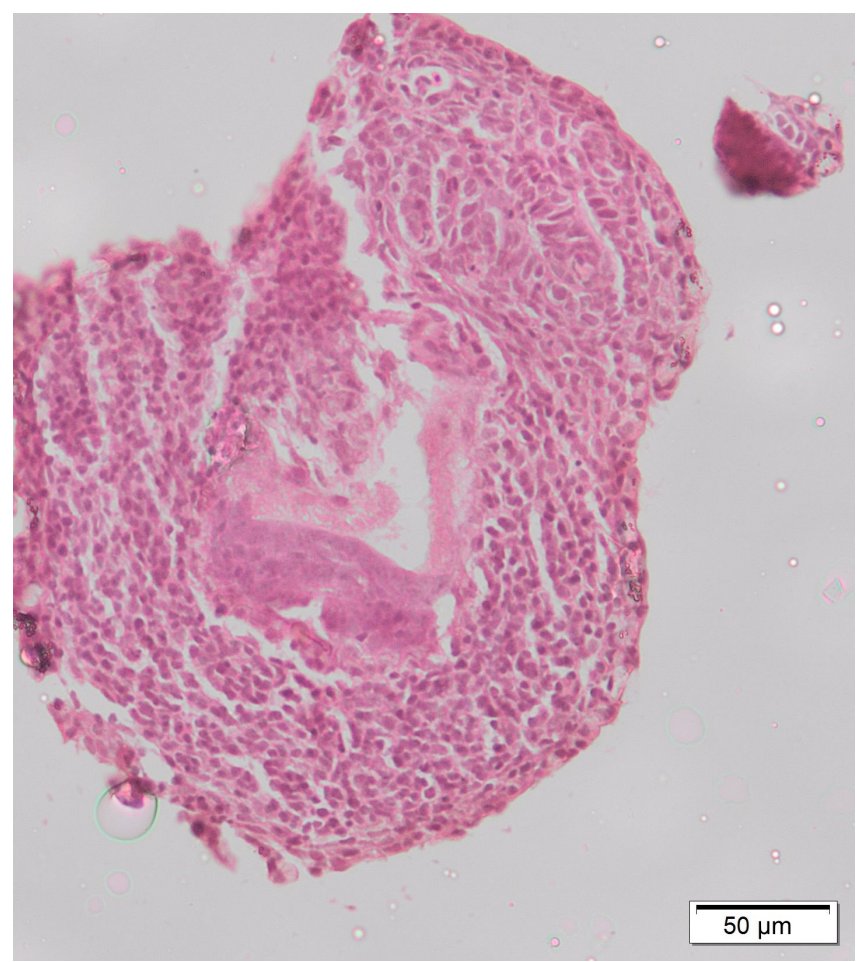

Fig. 8. Glochidium in a cyst on the gills of Salmo salar from the River Vuokinjoki in early October. Staining: haematoxylin and eosin; magnification: $\times 20$; scale: $50 \mu \mathrm{m}$. 
Glochidia from the River Vuokinjoki were characterised by a higher elongation compared with larvae from the River Kamennaya (1.46 $\mu \mathrm{m}$ and $1.34 \mu \mathrm{m}$, respectively). The largest and the smallest cyst sizes were on average $27 \%$ higher in glochidia from the River Vuokinjoki. At the same time, the elongation parameter was higher in cysts of $M$. margaritifera larvae from the River Kamennaya in comparison with those from the River Vuokinjoki $(1.59 \mu \mathrm{m}$ and $1.32 \mu \mathrm{m}$, respectively). These differences are supposedly associated with the parameter «cyst wall thickness».

The values of the parameter «cyst wall thickness along the major axis» in glochidia from the two studied rivers were not significantly different. This might be due to the different shape of the formed cysts. So, cysts from the River Kamennaya had an elongated, oval shape, whereas the ones from the River Vuokinjoki were rounded, spherical and, as a result, less elongated. On the other hand, the parameter «cyst wall thickness along the smaller axis»» was significantly higher for cysts from the River Vuokinjoki compared to the River Kamennaya (Table 5).

\section{Conclusions}

In the River Kamennaya system, $S$. salar is the only intermediate host available for $M$. margaritifera. Hence, well-being of the $S$. salar population is a major precondition for the life and sustainability of the unique $M$. margaritifera colony in the Kostomuksha State Nature Reserve.

In the Tsar Porog rapid, the M. margaritifera abundance was not high, with assemblages not exceeding 6-8 individuals per $1 \mathrm{~m}^{2}$, often with individuals occurring solely, $1-1.5 \mathrm{~m}$ apart. Older age groups (total length $12-14 \mathrm{~cm}$ ) prevailed in the colony, but younger individuals $(5-7 \mathrm{~cm})$ were present, too.

A comparison of the growth parameters obtained in our study with data on other M. margaritifera populations in Karelia and the Murmansk Region reveals a reliable $(\mathrm{p}<0.01)$ negative correlation between growth deceleration coefficients and the mean annual temperature at the studied location. Like in other populations, M. margaritifera growth in the River Kamennaya included three regular biorhythms. The biorhythm periods were roughly constant both through an individual ontogeny and among M. margaritifera individuals. They averaged 11.5 years, 6.4 years and 4.0 years. The periods of the first and last biorhythms did not differ between M. margaritifera populations.
A majority $(90.9 \%)$ of the studied S. salar juveniles were infected, regardless of their age, although the infection intensity was low, ranging from 1 to 19 glochidia per fish. The relatively low level of glochidial infection in the juveniles is probably due to the long distance to the donor $M$. margaritifera colony. No significant dependence of the infection intensity on the age, size or body weight of the host fish was revealed.

These studies and the assessment of the current ecological status of the $M$. margaritifera population in the Tsar Porog rapid area prove that recovery actions are needed to ensure preservation of the colony. One of the possible ways to increase the number of colonies in the long term is to transfer $M$. margaritifera into locations with a high density of young $S$. salar individuals. The resettlement of mature $M$. margaritifera individuals into places of $S$. salar parr habitation in autumn will create the conditions for increased juvenile $S$. salar infestation, thus securing the formation of a new colony.

\section{Acknowledgements}

We are thankful to MSc student Ksenia A. Filippova for her assistance in histomorphological analysis of host gills and glochidia. The research was carried out with partial funding from ENI-CBC Kolarctic project, SALMUS, KO1017 «Salmonid Fish and Freshwater Pearl Mussel - Ecosystem Services and Biodiversity in the Green Belt of Fennoscandia». The work of A.A. Zotin was carried out in the framework of the section of the state task of the Koltzov Institute of Developmental Biology, Russian Academy of Sciences, 2020 no. 0108-2019-0003. The research was conducted within the framework of the state assignment to KarRC RAS No. 02182019-0076; 0218-2019-0075; № 0218-2019-0081.

\section{References}

Alimov A.F. 1981. Functional Ecology of Freshwater Bivalves. Leningrad: Nauka. 248 p. [In Russian]

Arendt A., Heinen P., Molitor M., Mullet T., Thielen F. 2010. Restauration des populations de moules perlières en Ardennes. Rapport d'activité annuel (Période du ler août au 31 juillet 2010). Fondation Hëllef fir d'Natur. $118 \mathrm{p}$.

Artemyev A.V. 2007. Red Data Book of the Republic of Karelia. Petrozavodsk: Petrozavodsk State University. 364 p. [In Russian]

Bauer G. 1986. The status of the freshwater pearl mussel Margaritifera margaritifera L. in the south of its European range. Biological Conservation 38(1): 1-9. DOI: 10.1016/0006-3207(86)90015-7

Bauer G. 1988. Threats to the freshwater pearl mussel Margaritifera margaritifera L. in Central Europe. Biological Conservation 45(4): 239-253. DOI: 10.1016/00063207(88)90056-0 
Bauer G. 1992. Variation in the Life Span and Size of the Freshwater Pearl Mussel. Journal of Animal Ecology 61(2): 425-436. DOI: 10.2307/5333

von Bertalanffy L. 1960. Principles and theory of growth. In: Fundamental Aspects of Normal and Malignant Growth. Amsterdam: Elsevier. P. 137-259.

Bohlin T. 1984. Quantitative electrofishing for salmon and trout - views and recommendations. Information från Sötvattenslaboratoriet 4: 1-33.

Bruno D.W., McVicar A.H., Waddell I.F. 1988. Natural infection of farmed Atlantic salmon, Salmo salar L., parr by glochidia of the freshwater pearl mussel, Margaritifera margaritifera L. Bulletin of the European Association of Fish Pathologists 8(2): 23-26.

Bush A.O., Lafferty K.D., Lotz J.M., Shostak A.W. 1997. Parasitology meets ecology on its own terms: Margolis et al. Revisited. Journal of Parasitology 83(4): 575583. DOI: $10.2307 / 3284227$

Bykhovskaya-Pavlovskaya I.E. 1985. Fish Parasites. Study Manual. Leningrad: Nauka. 123 p. [In Russian]

CLIMATE-DATA.ORG. 2020. Climate data of cities worldwide. Available from: https://ru.climate-data.org/

Cochet G. 2004. La moule perlière et les nayades de France. Histoire d'une sauvegarde. Nohanent: Catiche production. $32 \mathrm{p}$.

Council of Europe. 1979. Convention on the conservation of European wildlife and natural heritage. Bern: Switzerland. Available from: http://conventions.coe.int/Treaty/ EN/Treaties/Html/104.htm

Denic M., Geist J. 2017. The freshwater pearl mussel Margaritifera margaritifera in Bavaria, Germany - Population status, conservation efforts and challenges. Biology Bulletin 44(1): 61-66. DOI: 10.1134/S1062359017010034

Dolmen D., Kleiven E. 2008. Distribution, status and threats of the freshwater pearl mussel Margaritifera margaritifera (Linnaeus) (Bivalvia, Margaritiferidae) in Norway. Fauna Norvegica 26/27: 3-14. DOI: $10.5324 /$ fn.v26i0.569

Dunca E., Mutvei H. 2009. Aldersbestämning av unga flodpärlmusslor $i$ Sverige. Sweden: WWF. 24 p.

Dunca E., Söderberg H., Norrgrann O. 2011. Shell growth and age determination in the freshwater pearl mussel Margaritifera margaritifera in Sweden: natural versus limed streams. Ferrantia 64: 48-58.

Dyduch-Falniowska A., Zając K. 2005. Margaritifera margaritifera (Linneaus, 1758) eastern pearlshell: freshwater pearl mussel. Polska czerwona księga zwierząt. bezkregowce Vol. 1. 447 p.

Geist J. 2010. Strategies for the conservation of endangered freshwater pearl mussels (Margaritifera margaritifera L.): a synthesis of Conservation Genetics and Ecology. Hydrobiologia 644(1): 69-88. DOI: 10.1007/s10750-010-0190-2

Gumpinger C., Pichler-Scheder C., Huemer D. 2016. Das oberösterreichische Artenschutzprojekt «Vision Flussperlmuschel». Österreichs Fischerei 69: 259-273.

Hastie L.C., Young M.R., Boon P.J. 2000. Growth characteristics of freshwater pearl mussels, Margaritifera margaritifera (L.). Freshwater Biology 43(2): 243-256. DOI: 10.1046/j.1365-2427.2000.00544.x

Ieshko E.P., Geist J., Murzina S.A., Veselov A.E., Lebedeva D.I., Ziuganov V.V. 2016. The characteristics of the infection of juvenile Atlantic salmon with glochidia of the freshwater pearl mussel in rivers of Northwest Russia. Knowledge and Management of Aquatic Ecosystems 417: 6. DOI: 10.1051/kmae $/ 2015039$

Inha I.K. 1999. Kalevalan laulumailta. Toim. Pekka Laaksonen. Suomalaisen Kirjallisuuden Seuran Toimituksia 739. Helsinki: SKS. 437 p.

IUCN. 2020. The IUCN Red List of Threatened Species. Version 2020-2. Available from: https://www.iucnredlist.org

Ivanter E.V., Korosov A.V. 2010. Elementary Biometrics. Petrozavodsk: Petrozavosk State University. 104 p. [In Russian]

Karna D.W., Millemann R.E. 1978. Glochidiosis of salmonid fishes. III. Comparative susceptibility to natural infection with Margaritifera margaritifera (L.) (Pelecypoda: Margaritanidae) and associated histopathology. Journal of Parasitology 64(3): 528-537. DOI: 10.2307/3279799

Kennedy M.K., Van Guelpen L., Pohle G., Bajona L. (Eds.). 2020. Canadian Register of Marine Species. Available from: http://www.marinespecies.org/carms on 2020-06-08

Kotiranta H., Uotila P., Sulkava S., Peltonen S.L. (Eds.) 1998. Red Data Book of East Fennoscandia. Helsinki: Ministry Environ. 344 p.

Lavictoire L., Ramsey A.D., Moorkens E.A., Souch G., Barnhart M.C. 2018. Ontogeny of juvenile freshwater pearl mussels, Margaritifera margaritifera (Bivalvia: Margaritiferidae). PLoS ONE 13(3): e0193637. DOI: 10.1371/journal.pone.0193637

Makhrov A., Bespalaya J., Bolotov I., Vikhrev I., Gofarov M., Alekseeva Y., Zotin A. 2014. Historical geography of pearl harvesting and current status of populations of freshwater pearl mussel Margaritifera margaritifera (L.) in the western part of Northern European Russia. Hydrobiologia 735(1): 149-159. DOI: 10.1007/s10750-013-1546-1

Malek-Mansour M., Nicolis G., Prigogine I. 1980. Nonequilibrium phase transitions in chemical systems. In: A.I. Zotin (Ed.): Termodynamics and kinetics of biological processes. Moscow: Nauka. P. 59-83. [In Russian]

Meyers T.R., Millemann R.E. 1977. Glochidiosis of salmonid fishes. I. Comparative susceptibility to experimental infection with Margaritifera margaritifera (L.) (Pelecypoda: Margaritanidae). Journal of Parasitology 63(4): 728-733. DOI: $10.2307 / 3279583$

Mikodina E.V., Sedova M.A., Chmilevsky D.A., Mikulin A.E., Pyanova S.V., Poluektova O.G. 2009. Histology for ichthyologists: experience and advices. Moscow: VNIRO. 111 p. [In Russian]

Moorkens E. 2010. Addressing the conservation and rehabilitation of Margaritifera margaritifera populations in the republic of Ireland within the framework of the habitats and species directive. Journal of Conchology 40(3): 339-350.

Motte G., Terren S., Bocca S., Collas P. 2013. Conservation of habitats of freshwater pearl mussel (Margaritifera 
margaritifera). In: International Meeting on Improving the environment for the Freshwater Pearl Mussel. Kerfermarkt, Austria.

Murzina S.A., Ieshko E.P., Zotin A.A. 2017. The freshwater pearl mussel Margaritifera margaritifera L.: metamorphosis, growth, and development dynamics of encysted glochidia. Biology Bulletin 44(1): 6-13. DOI: 10.1134/ S106235901701006X

Nezlin L.P., Cunjak R.A., Zotin A.A., Ziuganov V.V. 1994. Glochidium morphology of the freshwater pearl mussel (Margaritifera margaritifera) and glochidiosis of Atlantic salmon (Salmo salar): a study by scanning electron microscopy. Canadian Journal of Zoology 72(1): 15-21. DOI: 10.1139/z94-003

Olofsson P. 2017. Regional monitoring of freshwater pearl mussel Margaritifera margaritifera in the County of Norrbotten, Sweden. Biology Bulletin 44(1): 74-80. DOI: $10.1134 / \mathrm{S} 1062359017010095$

Oulasvirta P. 2010. Freshwater pearl mussel in Kamennaya River - expedition to the Kostamuksha State Nature Reserve, NW Russia. In: E.P. Ieshko, T. Lindholm (Eds.): Conservation of the freshwater pearl mussel Margaritifera margaritifera populations in Northern Europe. Petrozavodsk: Karelian Research Centre of RAS. P. 64-68.

Oulasvirta P., Leinikki J., Syväranta J. 2017. Freshwater pearl mussel in Finland - current status and future prospects. Biology Bulletin 44(1): 81-91. DOI: 10.1134/ S1062359017010101

Outeiro A., Ondina P., Fernández C., Amaro R., San Miguel E. 2007. Population density and age structure of the freshwater pearl mussel, Margaritifera margaritifera, in two Iberian rivers. Freshwater Biology 53(3): 485496. DOI: 10.1111/j.1365-2427.2007.01913.x

Prigogine I. 1972. La thermodynamique de la vie. La Recherche 3(24): 547-562.

Rozsa L., Reiczigel J., Majoros G. 2000. Quantifying parasites in samples of hosts. Journal of Parasitology 86(2): 228-232. DOI: 10.1645/0022-3395(2000)086[0228:QP ISOH]2.0.CO;2

Rudzīte M., Rudzītis M., Birzaks J. 2017. The populations of the freshwater pearl mussel, Margaritifera margaritifera (Linnaeus, 1758), and the thick shelled river mussel, Unio crassus Philipsson, 1788, in Latvia. Biology Bulletin 44(1): 99-107. DOI: 10.1134/ S1062359017010125

San Miguel E., Monserrat S., Fernández C., Amaro R., Hermida M., Ondina P., Altaba C.R. 2004. Growth models and longevity of freshwater pearl mussels (Margaritifera margaritifera) in Spain. Canadian Journal of Zoology 82(8): 1370-1379. DOI: 10.1139/z04-113

Shapiro S.S., Wilk M.B. 1965. An analysis of variance test for normality. Biometrika 52(3): 591-611.

Simon O.P., Vaníčková I., Bílỳ M., Douda K., Patzenhauerová H., Hruška J., Peltánová A. 2015. The status of freshwater pearl mussel in the Czech Republic: several successfully rejuvenated populations but the absence of natural reproduction. Limnologica 50: 11-20. DOI: 10.1016/j.limno.2014.11.004
Sousa R., Amorim A., Sobral C., Froufe E., Varandas S., Teixeira A., Lopes-Lima M. 2013. Ecological Status of a Margaritifera margaritifera (Linnaeus, 1758) Population at the Southern Edge of its Distribution (River Paiva, Portugal). Environmental Management 52(5): 1230-1238. DOI: 10.1007/s00267-013-0117-6

Studenov I.I. 2000. Review of methods for assessing the production of salmon rivers. Arkhangelsk. 47 p. [In Russian]

Van Valen L. 1973. A new evolutionary law. Evolutionary Theory 1: 1-30.

Young M., Williams J. 1984. The reproductive biology of the freshwater pearl mussel Margaritifera margaritifera (Linn.) in Scotland I. Field studies. Archiv für Hydrobiologie 99(4): 405-422.

Young M.R., Cosgrove P.J., Hastie L.C. 2001. The extent of, and causes for, the decline of a highly threatened naiad: Margaritifera margaritifera. In: G. Bauer, K. Wächtler (Eds.): Ecology and Evolution of the Freshwater Mussels Unionoida. Vol. 145. Berlin: Springer-Verlag. P. 337-357. DOI: 10.1007/978-3-642-56869-5_19

Zippin C. 1956. An Evaluation of the Removal Method of Estimating Animal Populations. Biometrics 12(2): 163189. DOI: $10.2307 / 3001759$

Ziuganov V.V., Zotin A.A. 2001. Freshwater pearl mussel Margaritifera margaritifera (Linnaeus, 1758). In: Red Data Book of the Russian Federation (Animals). Moscow: Astrel'. P. 61-62. [In Russian]

Ziuganov V., Zotin A., Nezlin L., Tretiakov V. 1994. The freshwater pearl mussels and their relationships with salmonid fish. Moscow: VNIRO. $104 \mathrm{p}$.

Zolotarev V.N. 1974. Multiannual rhythms of growth of mussel L. grayana shell. Ekologiya 3: 76-80. [In Russian]

Zotin A.A. 2000. Statistical estimation of allometric coefficients. Biology Bulletin 27(5): 431-437. [In Russian]

Zotin A.A. 2009. Patterns of growth and energy metabolism in the ontogeny of mollusks. Dr.Sc. Thesis Abstract. Moscow. 30 p. [In Russian]

Zotin A.A. 2014. Why linear thermodynamics does describe change of entropy production in living systems? Natural Science 6(7): 495-502. DOI: 10.4236/ns.2014.67048

Zotin A.A. 2020. Growth biorhythms of the European pearl mussel Margaritifera margaritifera (Bivalvia, Margaritiferidae). Varzuga River Population (Murmansk Region). Biology Bulletin 47(4): 368-375.

Zotin A.A., Ieshko E.P. 2017. Comparative analysis of the growth of Margaritifera margaritifera (Bivalvia) from different populations of Karelia and Kola Peninsula. Biology Bulletin 44(1): 1-5. DOI: 10.1134/ S1062359017010186

Zotin A.A., Ieshko E.P. 2018. Biorhythms of Margaritifera margaritifera (Bivalvia, Margaritiferidae) freshwater pearl mussel growth: population of Syuskyuyanioki River (Karelia). Russian Journal of Developmental Biology 49(4): 206-213. DOI: $10.1134 / \mathrm{S} 1062360418040082$

Zotin A.A., Ieshko E.P. 2020. Biorhythms of Margaritifera margaritifera (Bivalvia, Margaritiferidae) freshwater pearl mussel growth: population of Nemina River (Karelia). Biology Bulletin. [In press] 
Zotin A.A., Kleimenov S.Yu. 2013. Endogenous biorhythms of the specific growth rate in individual development of Lymnaea stagnalis (Lymnaeidae, Gastropoda). Biology Bulletin 40(1): 1-10. DOI: 10.1134/ S1062359013010147

Zotin A.A., Murzina S.A., Ieshko E.P. 2018. Growth biorhythms in the freshwater pearl mussel Margaritifera margaritifera (Bivalvia, Margaritiferi- dae). Livojoki river population (Karelia). Knowledge and management of aquatic ecosystems 419: 44. DOI: $10.1051 / \mathrm{kmae} / 2018033$

Zotin A.A., Murzina S.A., Bystrova K.A., Ieshko E.P. 2020. Growth Parameters of the Freshwater Pearl Mussel Margaritifera margaritifera (Bivalvia, Margaritiferidae), Vuokinjoki River Population (Karelia). Malacologia 63(1): 67-75. DOI: 10.4002/040.063.0107

\title{
ЭКОЛОГИЧЕСКИЕ ХАРАКТЕРИСТИКИ MARGARITIFERA MARGARITIFERA (BIVALVIA, MARGARITIFERIDAE) РЕКИ КАМЕННАЯ (БАССЕЙН БЕЛОГО МОРЯ)
}

\author{
А. А. Зотин ${ }^{1}$, С. А. Мурзина ${ }^{\mathbb{D}}$, Д. А. Ефремов ${ }^{2}$, П. Оуласвирта ${ }^{3}$, Е. П. Иешко $\mathbb{1}$ \\ ${ }^{1}$ Институт биологии развития им. Н.К. Кольияова РАН, Россия \\ e-mail:aazotin@mail.ru \\ ${ }^{2}$ Институт биологии Карельского научного иентра РАН, Россия \\ e-mail:murzina.svetlana@gmail.com,denisefremov@list.ru,ieshkoep@gmail.com \\ ${ }^{3}$ Alleco Ltd., Finland \\ e-mail:panu.oulasvirta@alleco.fi
}

\begin{abstract}
Изучались условия совместного обитания молоди пресноводного лосося Salmo salar и моллюска Margaritifera margaritifera в р. Каменная (водосборная область р. Кемь, бассейн Белого моря). Популяция M. margaritifera в р. Каменная насчитывает около 1000 экземпляров. Единственным промежуточным хозяином, способным поддерживать существование M. margaritifera на Европейском севере, является молодь Salmo salar. В настоящей работе изучен ряд параметров и процессов, позволяющих лучше понять экологию M. margaritifera. Одним из таких параметров, исследованных у M. margaritifera $\mathrm{p}$. Каменная, является индивидуальный линейный рост. Показано, что коэффициенты замедления роста варьировали в широком диапазоне и значительно различались на индивидуальном уровне. Средний для всей популяции коэффициент замедления роста составил 0.076. В росте M. margaritifera в р. Каменная выявлены три закономерных биоритма с периодами, составляющими 11.5, 6.4 и 4.0 лет. Периоды каждого из биоритмов были относительно постоянными как на протяжении онтогенеза отдельных особей, так и у разных особей. Сравнение полученных результатов с данными по другим популяциям M. margaritifera Республики Карелия и Мурманской области выявило наличие достоверной $(p<0.01)$ отрицательной корреляции между коэффициентами замедления роста и среднегодовой температурой в месте обитания M. margaritifera. Представлены данные по численности, пространственному распределению и возрастной структуре молоди $S$. salar и $M$. margaritifera. Проведена оценка уровней зараженности разновозрастной молоди $S$. salar глохидиями M. margaritifera. При помощи гистологических методов охарактеризованы стадии развития и состояние глохидий M. margaritifera, образовавших цисты на жабрах молоди S. salar. Результаты настоящего исследования будут использованы для подготовки рекомендаций по мерам для сохранения популяций $M$. margaritifera и $S$. salar в р. Каменная. Прежде всего, это касается увеличения численности молоди S. salar и заселения M. margaritifera порогов р. Каменная с высокой плотностью молоди.
\end{abstract}

Ключевые слова: Salmo salar, атлантический лосось, глохидии, заражение, пресноводная жемчужница, рост, сохранение исчезающих видов 